\title{
Bartholin Gland Adenomyoma
}

National Cancer Institute

\section{Source}

National Cancer Institute. Bartholin Gland Adenomyoma. NCI Thesaurus. Code C40300.

A rare, benign neoplasm that arises from the Bartholin gland and is characterized by the presence of a fibromuscular stroma and glands lined by mucin-secreting epithelial cells, arranged in a lobular architecture. 